\title{
A inclusão do sujeito surdo no ensino regular do ponto de vista de alunos surdos, familiares, professores e intérpretes
}

\author{
Daline Backes Eyng ${ }^{1}$
}

Eyng DB. A inclusão do sujeito surdo no ensino regular do ponto de vista de alunos surdos, familiares, professores e intérpretes [dissertação]. Curitiba: Universidade Tuiuti do Paraná; 2012.

O objetivo dessa pesquisa foi apresentar a prática de inclusão de surdos, matriculados no ensino regular do município de Medianeira/PR, sob a percepção de professores, intérpretes, familiares e alunos surdos, além de apontar sugestões desses grupos para a melhoria desse processo. Com a proposta de oportunizar ao leitor a compreensão do processo de apropriação da linguagem no sujeito surdo, este estudo descreve o desenvolvimento da linguagem no contexto da surdez, além da contribuição da língua de sinais no contexto educacional a que o surdo está matriculado, preconizando a adoção de uma educação bilíngue. Para atender o objetivo proposto, foram aplicados questionários aos quatro grupos de sujeitos, a fim de verificar como se processa a prática de inclusão desses alunos no ensino regular. Os resultados da pesquisa demonstraram contradições entre a proposta de inclusão escolar de surdos e a prática realizada nas escolas, onde a pesquisa foi realizada. Os sujeitos apresentaram percepções que consideram a inclusão efetiva, porém apontaram, no decorrer do questionário, falhas nesse processo. Além disso, foram elencadas também sugestões para a melhoria na inclusão educacional de surdos, sob a perspectiva dos sujeitos, sendo as principais: uso de metodologia diferenciada; inserção da Libras no currículo de formação de docentes; maior aceitação do surdo pela comunidade escolar; atendimento educacional especializado para o aluno surdo; e, avaliação constante da apropriação de conteúdos por esses alunos. A pesquisa demonstrou que professores e intérpretes tem a percepção de que são necessários ajustes no processo educacional inclusivo, porém, para os familiares e alunos surdos, a inclusão está acontecendo. Receber e matricular surdos no ensino regular não contempla a necessidade de apropriação do conhecimento desses alunos. Para que isso ocorra, são necessárias várias modificações no sistema educacional brasileiro, como metodologias apropriadas para a realidade visual do aluno surdo, adaptações curriculares e a adoção de Políticas Públicas que atendam as diretrizes da proposta inclusiva. Dessa forma, a pesquisa demonstrou a importância da participação de todos os sujeitos (professores, intérpretes, familiares e alunos surdos) na reorganização da escola na perspectiva da educação inclusiva, cabendo a cada um, uma parcela de responsabilidade nesse processo educacional.

Trabalho apresentado ao Programa de Pós-graduação em Distúrbios da Comunicação, Universidade Tuiuti do Paraná - UTP - Curitiba (SP), Brasil, para obtenção do título de Mestre em Distúrbios da Comunicação, sob orientação da Profa. Dra. Ana Cristina Guarinello.

(1) Programa de Pós-graduação em Distúrbios da Comunicação, Universidade Tuiuti do Paraná - UTP - Curitiba (SP), Brasil.

Endereço para correspondência: Daline Backes Eyng. R. Getúlio Vargas, 2230/2, Cidade Alta, Medianeira (PR), Brasil, CEP: 85884-000. E-mail: dalinebackes@hotmail.com 